\title{
Cooperative and adaptive transboundary water governance in Canada's Mackenzie River Basin: status and prospects
}

\author{
Michelle Morris $^{1,2}$ and Rob C. de Loë ${ }^{1,2}$
}

\begin{abstract}
Canada's Mackenzie River Basin (MRB) is one of the largest relatively pristine ecosystems in North America. Home to indigenous peoples for millennia, the basin is also the site of increasing resource development, notably fossil fuels, hydroelectric power resources, minerals, and forests. Three provinces, three territories, the Canadian federal government, and Aboriginal governments (under Canada's constitution, indigenous peoples are referred to as "Aboriginal") have responsibilities for water in the basin, making the MRB a significant setting for cooperative, transboundary water governance. A framework agreement that provides broad principles and establishes a river basin organization, the MRB Board, has been in place since 1997. However, significant progress on completing bilateral agreements under the 1997 Mackenzie River Basin Transboundary Waters Master Agreement has only occurred since 2010. We considered the performance of the MRB Board relative to its coordination function, accountability, legitimacy, and overall environmental effectiveness. This allowed us to address the extent to which governance based on river basin boundaries, a bioregional approach, could contribute to adaptive governance in the MRB. Insights were based on analysis of key documents and published studies, 19 key informant interviews, and additional interactions with parties involved in basin governance. We found that the MRB Board's composition, its lack of funding and staffing, and the unwillingness of the governments to empower it to play the role envisioned in the Master Agreement mean that as constituted, the board faces challenges in implementing a basin-wide vision. This appears to be by design. The MRB governments have instead used the bilateral agreements under the Master Agreement as the primary mechanism through which transboundary governance will occur. A commitment to coordinating across the bilateral agreements is needed to enhance the prospects for adaptive governance in the basin.
\end{abstract}

Key Words: adaptive governance; bioregional approach; Mackenzie River Basin Board; Mackenzie River Basin, Canada; river basin organizations; transboundary water governance

\section{INTRODUCTION}

The Mackenzie River Basin (MRB) is one of the largest relatively pristine riverine ecosystems in North America (Rosenberg International Forum on Water Policy 2013). It is also a site of increasing resource development within Canada, and a transboundary system in which three provinces, three territories, a federal government, and Aboriginal governments (under Canada's constitution, indigenous peoples are referred to as "Aboriginal") have responsibilities for water. We argue, as others have (Delli Priscoli and Wolf 2009, Garrick et al. 2014), that transboundary water governance within federal countries can face challenges similar to those between sovereign states in the international context. Evidence for this assertion is easy to collect; consider conflicts over water use in the ApalachicolaChattahoochee-Flint Basin the United States (Meruelo 2007), the Narmada river system in India (Kumar 2014), or the MurrayDarling Basin in Australia (Bhat 2009). In the MRB, concerns regarding the downstream impacts of hydroelectric development have persisted for decades. More recently, the environmental impacts of increasing oil and gas extraction have emerged as major concerns.

To illustrate the scope and nature of these challenges, upstream hydroelectric developments have altered natural flow patterns. Oil sands extraction has resulted in habitat fragmentation and impacts to water quality; Aboriginal peoples report deteriorating water quality and poor fish health downstream of oil sands mines (MRBB 2012). Changing temperatures in the MRB have impacted the timing of spring thaw, fall freeze-up, and peak river flows; the basin's hydrology may also be impacted by increased permafrost thawing (MRBB 2012). These changes may impact the quality and quantity of water available for human settlements and resource development. Transboundary water governance that respects the interests of the diversity of indigenous peoples in the MRB is also a key challenge. A coordinated and adaptive approach to transboundary governance may help to address uncertainties associated with climate change and increasing industrial development in the MRB, as well as fostering greater inclusion in environmental monitoring and decision making. How Canadians address the challenge of cooperative and adaptive governance in this basin can provide insights for both scholars and practitioners of transboundary water management.

Adaptive governance emphasizes learning and experimentation, which can foster conditions that help to deal with complexities and uncertainties in social-ecological systems (Chaffin et al. 2014), including those that exist in transboundary water systems such as the MRB. Adaptive transboundary water governance is characterized by features such as incorporating a variety of knowledges, i.e., local, traditional, and scientific, in monitoring and decision making, and institutions that are flexible to allow responses to new information (Raadgever et al. 2008). Vertical and horizontal information sharing and the presence of nested institutions can help to facilitate adaptive transboundary water governance by enabling well-informed and coordinated management responses to take place at the appropriate scale (Folke et al. 2005, Akamani and Wilson 2011, Green et al. 2013). Joint institutions such as river basin organizations, which operate on the scale of the bioregion, are considered key facilitators of adaptive governance in transboundary systems (De Stefano et al. 2012, Green et al. 2013). However, as D. Huitema and S. Meijerink (unpublished manuscript) point out, there is a great degree of 
variability in terms of river basin organization form and function. Thus, assessing the extent to which river basin organizations can contribute to adaptive governance requires considering their institutional design and performance. We evaluated how well a river basin organization that operates in the MRB, the Mackenzie River Basin Board (MRB Board), performs in terms of coordination, accountability, legitimacy, and environmental effectiveness. Using these criteria of institutional performance, we also considered the extent to which governance based on river basin boundaries, a bioregional approach (Slocombe 1998), contributes to adaptive governance in the MRB. Effectively enabling an adaptive, bioregional approach to governance requires appropriate institutions and a supportive political context (Folke et al. 2005). Without accountability, legitimacy, and evidence of effectiveness, sustaining interest in adaptive governance can be difficult (Cosens and Williams 2012). Thus, institutional design and performance can be critical to enabling adaptive governance.

The MRB Board, a coordinating river basin organization, was established in 1997 under the Mackenzie River Basin Transboundary Waters Master Agreement (henceforth referred to as the Master Agreement; Government of Canada et al. 1997) to encourage cooperative management based on principles of ecosystem integrity, sustainability, and respect for jurisdictional autonomy. In this paper, we discuss our findings related to the design of the MRB Board, and the politics and strategies that resulted in this design; the effectiveness of the board; and the the extent to which the board contributes to a bioregional, adaptive approach to governance in the basin.

Our findings were based on several sources of information. A total of 118 documents, including government documents, technical reports, submissions to environmental assessment hearings, news articles, and documents produced by Aboriginal governments and environmental organizations informed our analysis. Nineteen semistructured interviews with key informants directly involved in governance for water in the basin provided a rich source of data regarding experiences with and perceptions of the MRB Board and transboundary governance in the basin. Interviews were transcribed verbatim and verified by participants. Personal observations made by the first author during environmental assessment hearings and meetings and the personal experiences of the second author, based on his role as a former member of the Northwest Territories (NWT) Strategic Advisory Group of Experts regarding transboundary negotiations, also supported our analysis. Interview data and policy documents were analyzed according to principles of institutional design and evaluation criteria related to coordination, accountability, legitimacy, and environmental effectiveness discussed by D. Huitema and S. Meijerink (unpublished manuscript). Data were also considered for indicators of adaptive transboundary water governance, including nested, multilevel design, the inclusion of multiple sources of information in monitoring and decision making, and flexibility/responsiveness.

\section{CASE AND CONTEXT}

Even in a country recognized globally for its considerable water resources, the MRB (Fig. 1) stands out. It contains Canada's longest river system, at $4241 \mathrm{~km}$ (MRBB 2003). With an area of approximately 1.8 million $\mathrm{km}^{2}$, the basin drains approximately one-fifth of Canada's land area (MRBB 2003). The basin's headwaters are the Peace and Athabasca rivers, which begin in British Columbia and Alberta, respectively. Numerous lakes, including the largest lake entirely in Canada (Great Bear) and the deepest lake in North America (Great Slave), along with internationally significant deltas and vast wetlands, are part of the basin's hydrology. The waters of the basin ultimately discharge from the Mackenzie River into the Beaufort Sea on Canada's northern coast.

Fig. 1. The Mackenzie River Basin, Canada.

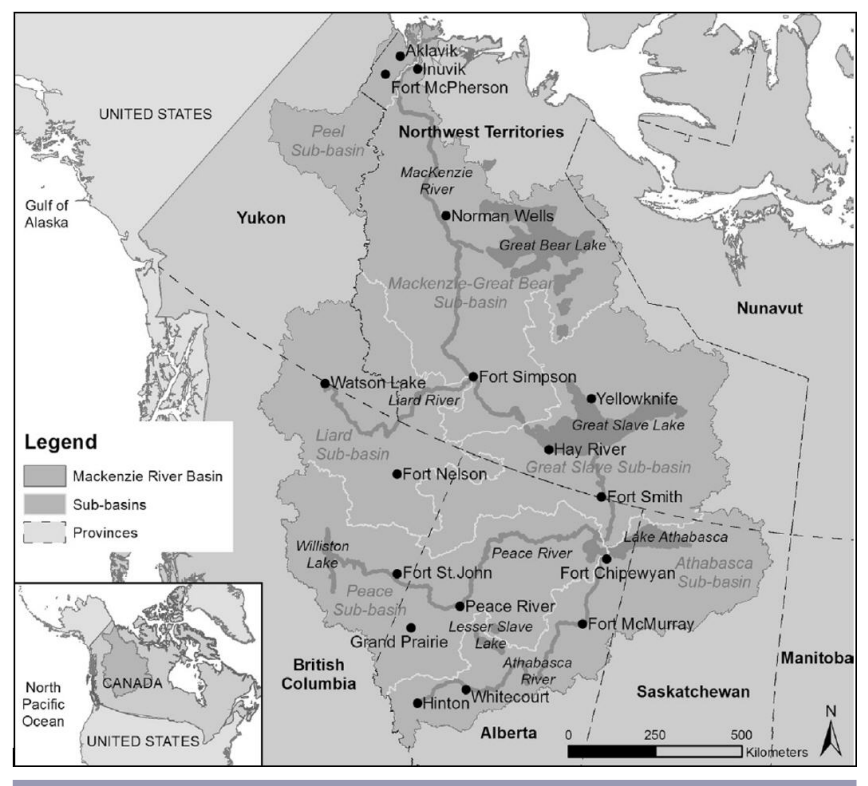

The basin's terrestrial and aquatic ecosystems are nationally and internationally significant. In addition to containing some of the last expanses of nearly pristine wilderness on the North American continent, the MRB also has globally significant wetland, tundra, and forest ecosystems; these provide habitat for numerous species that reside part or all of the year in the basin. Deltas provide critical staging and breeding zones for millions of migratory birds; examples include tundra swans and geese that use the PeaceAthabasca Delta on Lake Athabasca (Fig. 1). The Mackenzie Delta on the Beaufort Sea, Canada's largest active delta at approximately $9000 \mathrm{~km}^{2}$ (Prowse et al. 2009), is a critical habitat for species that include fish, beluga whales, moose, and beaver (MRBB 2003). The fish and wildlife resources of the basin are critical not only for their role in ecosystems, but also as a source of food for a significant portion of the basin's people, especially its Aboriginal peoples (GNWT 2010).

The MRB is sparsely populated relative to southern Canada. Its population in 2001 (the most recent date for which basin population data were calculated) was an estimated 397,000 people, the majority of whom resided in the Alberta portion (MRBB 2003). As in northern Canada as a whole (Prowse et al. 2009), population growth and demographic change have been closely linked to resource development. Development of Alberta's oil sands, near the town of Fort McMurray (Fig. 1), accounts for much of the basin's recent population growth. For example, 
between the 2006 and 2011 national census years, the population of Fort McMurray grew by approximately 30\% (Statistics Canada 2012). Much of this population growth is because of the labor demands of oil sands mining and construction (Regional Municipality of Wood Buffalo 2012). Aboriginal peoples, who constituted $15 \%$ of the 2001 population, have lived in the MRB for millennia. The proportion of the population that is Aboriginal is highest in the less densely populated northern portions of the basin (MRBB 2003), where communities tend to be small, i.e., fewer than 500 people, and located along coastlines, lakeshores, and rivers (Prowse et al. 2009).

Jurisdiction over the basin is shared and fragmented. Key actors include provinces, territories, the federal government, and Aboriginal peoples. The MRB Board was created in part to provide a coordinating function among these actors.

- Portions of the basin are located in three of Canada's provinces (Alberta, British Columbia, and Saskatchewan) and three territories (Yukon, NWT, and Nunavut, although Nunavut is not typically considered a basin jurisdiction because its share of the basin's land area is so small; Fig. 1). Under the Canadian Constitution, provinces have primary responsibility for the management of water resources; thus, each province has its own institutional framework for governing water.

- The federal government is also a key basin jurisdiction because of its constitutionally defined responsibilities relating to concerns such as fisheries, national parks, transboundary waters, and Aboriginal peoples.

- The Yukon Territory and the NWT have received provincelike powers from the federal government through devolution processes in 2003 and 2014, respectively.

- Indigenous peoples occupy a special place in Canada's society because of their historical, legal, treaty, and constitutionally defined rights. Hence, the fact that the basin includes the traditional territories, treaty areas, and land claim settlement regions of First Nations, Métis, and Inuvialuit (or western Canadian Inuit) peoples is critical to any discussion of transboundary water governance in the basin.

The basin is under pressure from a number of threats. A lack of adequate baseline environmental data in much of the basin has made tracking long-term environmental changes difficult (MRBB 2012). Climate change is an important current and future stressor on the basin's social and ecological systems (Schindler and Donahue 2006). Wolfe et al. (2012) anticipate declining spring freshet and summer discharge in the headwaters of the MRB. Some models indicate that annual discharge may increase in the Peace River region, with higher discharge in the fall and winter months but reduced discharge in the late summer and early fall (Schnorbus et al. 2011). Modeling future Athabasca River flows indicates a trend of decreasing flows, which is expected to continue because of declining glacier ice and snowpack at higher elevations (Sauchyn et al. 2015). There is some uncertainty about the impacts of the climate change in the basin. In general, water quality and quantity available for human settlements and resource developments are expected to fluctuate, making an adaptive approach necessary in this basin (MRBB 2012).
Energy development projects located in the Athabasca and Peace sub-basins are additional sources of social and environmental change in the MRB. Fossil fuel extraction is the predominant economic activity in the Athabasca sub-basin in Alberta. In 2014-2015, royalties collected from bitumen mining totaled approximately $\$ 5$ billion, more than half of those collected by the province (Government of Alberta 2015). Production from surface and in situ oil sands mines increased by approximately $74 \%$ between 2000 and 2014, from 0.66 million oil barrels per day to 2.3 million oil barrels per day (Alberta Energy and Utilities Board 2001, Alberta Energy Regulator 2015); production is expected to reach approximately 4.8 million oil barrels per day by 2030 (Alberta Energy Regulator 2015).

Oil sands development figures prominently in Alberta's economy, but it has also created large-scale environmental disturbances. More than $600 \mathrm{~km}^{2}$ of land is under development for oil sands mining and there are approximately $170 \mathrm{~km}^{2}$ of tailings ponds in the region (MRBB 2012), which contain naphthenic acids, polycyclic aromatic hydrocarbons, arsenic, and other trace metals (Timoney and Lee 2009). The most significant source of water for oil sands mining is the Athabasca River; mining requires on average 3.1 barrels of water per barrel of oil produced (Canadian Association of Petroleum Producers 2015). Processed water is stored in tailing ponds, which have been detected seeping into the Athabasca River and its tributaries (Timoney and Lee 2009). The scale and pace of oil sands development in Alberta are controversial because of local environmental impacts, including habitat fragmentation and destruction, pollution, and water use (Hodson 2013), as well as impacts to the Aboriginal and treaty rights and contribution to Canada's greenhouse gas emissions (Mantyka-Pringle et al. 2013). Concern regarding the environmental impacts of oil sands extraction extends to the downstream NWT (Aboriginal Affairs and Northern Development Canada and Government of the Northwest Territories 2011). In the late 2000s and early 2010s, several reports critiqued monitoring programs in the oil sands region for failing to provide necessary data to conduct assessments of cumulative effects (Auditor General of Canada 2011) or adequate sampling and baseline information to adequately assess industry's impact on the landscape (Kelly et al. 2010, Oil Sands Advisory Panel 2010). In response, the federal government and province of Alberta cooperated to develop a multiyear Joint Oil Sands Monitoring Program in 2012 (Government of Canada and Government of Alberta 2012). The MRB Board has not been directly engaged in this monitoring effort.

Electricity generated from hydroelectric power stations in the basin also is extremely important to the economy of British Columbia. Two stations located on the Peace River account for approximately $30 \%$ of generating capacity in the province (MRBB 2003). A third dam was approved by the provincial and federal governments in the fall of 2014. The environmental impacts of hydroelectric facilities on the Peace River have been long-standing concerns for downstream communities and governments (Northern River Basins Study Board 1996), who raised concerns during the environmental assessment for the third dam in 2013 and 2014 (GNWT 2013, Parks Canada 2013, Moore 2014). The Bennett Dam on the Peace River (Fig. 1) has resulted in changes to seasonal patterns of stream flow, i.e., higher flows in winter and lower flows in the spring, that have long been thought to have 
negatively affected the ecology of the Peace-Athabasca Delta (Prowse and Conly 2000). The extent to which changes experienced and observed in the Peace-Athabasca Delta are caused by climate change or the dam's flow regulation is currently a matter of debate. Some studies suggest that climate drivers are responsible (Wolfe et al. 2012), whereas others acknowledge that although climate change has had an impact, flow regulation is the more influential driver of downstream ecosystem disturbance (Beltaos 2014).

In summary, the MRB is a nationally significant bioregion. Critical ecological resources exist in a place that is immensely significant to indigenous peoples, who have occupied the landscape for millennia. Major economic developments exist, and many more are planned. Inadequate monitoring and baseline information means considerable uncertainty exists about the extent of environmental changes resulting from industrial development and climate change. Uncertainties associated with the extent of environmental changes resulting from climate change and industrial development, and the multiple interests at stake in the MRB, make an adaptive approach to governance in this basin desirable.

\section{POLITICS, STRATEGIES, AND INSTITUTIONAL DESIGN}

The jurisdictions that share the MRB have independent responsibilities for water resources. As a result, even though the basin is located entirely within Canada, the kinds of problems that are typical in shared international basins (Loures et al. 2008) also exist in this case. Recognizing this challenge, the basin jurisdictions began working toward a more cooperative approach to water management in the early 1970s (Creery 1979). These efforts coincided with a period of national leadership from the federal government and a relatively high degree of cooperation among the provinces and the federal government on water issues in Canada (Booth and Quinn 1995). This cooperative spirit has dissipated as the territories received province-like powers for resource management and cuts to federal environment ministries reduced the federal government's capacity for water-related matters (Clancy 2014). As noted above, although the federal government does possess constitutional jurisdiction for transboundary waters, in recent years it has largely deferred to subfederal governments regarding transboundary waters (Saunders 2014). Work on the agreement that created the MRB Board began in 1988 and proceeded through several iterations of negotiations and public comment. An agreement was drafted in the early 1990s and finalized in 1997 when the responsible ministers from each jurisdiction signed the Master Agreement (Government of Canada et al. 1997). The Master Agreement reflects the preferred style of intergovernmental cooperation in Canada during the 1990s, as well as key principles that were shaping discussions around ecosystems and transboundary water resources in the international realm during this time, e.g., information exchange, cooperation among watercourse states, and an ecosystem approach (Slocombe 1998, McCaffrey 2007). Table 1 summarizes how these preferences and principles were expressed in terms of the five institutional design rules discussed by D. Huitema and S. Meijerink (unpublished manuscript). Key underlying principles in Part $\mathrm{C}$ of the Master Agreement (Government of Canada et al. 1997:3-4) include the following:
Table 1. Rules underlying the institutional design of the Master Agreement and the Mackenzie River Basin Board.

\section{Rule-types Rules in case study}

Authority The Mackenzie River Basin Board has no rules independent authority of its own beyond the mandate it received from the parties to the Mackenzie River Basin Transboundary Waters Master Agreement. Instead, its mandate focuses on coordination, facilitation, dispute resolution, and information gathering and sharing.

Aggregation Decisions are made by super majority of two-thirds rules of the members of the board, although there are constraints on Aboriginal members (e.g., they are appointed at the pleasure of the respective ministers and they cannot pass resolutions or action items without the support of some government members).

Boundary The boundaries of the board's mandate are defined rules by the hydrologic basin, and the signatories to the Master Agreement have relatively well accepted territorial and constitutional jurisdictions. Entry and exit rules are specified in the agreement. Membership is limited to representatives of governments and to Aboriginal peoples (who are not considered as representatives of the general public).

Information The board has a mandate to conduct research and rules to generate information that contributes to a wholebasin perspective on problems of issues; thus, it has some scope to generate its own information.

Discussions around the board table are private, and minutes of these discussions are not publicly available.

Pay-off The annual budget for the board that was rules established in $1997, \$ 280,000$, is provided by the basin jurisdictions according to a clear formula specified in the Master Agreement. The budget has not been changed since 1997, meaning that the present value of the budget is significantly less than in 1997 because of inflation.

1. Managing the Water Resources in a manner consistent with the maintenance of the Ecological Integrity of the Aquatic Ecosystem;

2. Managing the use of Water Resources in a sustainable manner for present and future generations;

3. The right of each to use or manage the use of the Water Resources within its jurisdiction provided such use does not unreasonable harm the Ecological Integrity of the Aquatic Ecosystem in any other jurisdiction;

4. Providing for early and effective consultation, notification and sharing of information on development and activities that might affect the Ecological Integrity of the Aquatic Ecosystem in another jurisdiction;

5. Resolving issues in a cooperative and harmonious manner. 
The agreement does not define ecological integrity, sustainable management, or what constitutes cooperative management. Fulfilling these objectives depends on the substance of seven bilateral water management agreements to be negotiated between neighboring jurisdictions under the broad framework of the Master Agreement. The MRB Board can support the negotiation of these agreements, but it does not have an explicit negotiating role. As of October 2015, three bilateral agreements have been completed. One, between the Yukon and the NWT, was completed in 2000, and is considered by many to be outdated and in need of revision. In 2015, bilateral water management agreements were completed between the governments of Alberta and the NWT, and between British Columbia and the NWT. Four other bilateral agreements are currently being negotiated.

Section 2(D) of the Master Agreement created the river basin organization that is the focus of this article: the MRB Board. The boundaries of the Master Agreement and the jurisdiction of the MRB Board were hydrologically defined, and this boundary rule has not been contentious. When the agreement was negotiated, the hydrological boundaries established in previous studies were accepted as constituting the MRB Board's jurisdiction. Establishing the boundaries was apolitical because it was viewed as "a GIS [geographic information system] job and if somebody came and said the line needs to move a mile east or a mile west because they've now done more detailed GIS work . . . fine. That is not an issue" (key informant 4).

As defined by the Master Agreement, the MRB Board has up to three officials appointed by the federal government and one each appointed by the provinces and territories. If member jurisdictions wish to exit the agreement, the Master Agreement specifies that one year's notice to all of the other jurisdictions must be provided. A distinctive feature of the board's membership is the provision for five Aboriginal members. These members are elected by Aboriginal organizations in each of the provinces and territories, and are then appointed by the respective jurisdictions. Several board members have suggested that the inclusion of Aboriginal members brings a necessary perspective to the board (key informants 1 and 4). However, the MRB Board's aggregation rules require a super majority of two-thirds of members present to consent to a decision or undertaking. Therefore, in most cases Aboriginal members cannot pass resolutions or action items without the support of some government members.

The MRB Board's overall mandate is to support the principles of the Master Agreement and to provide a forum to coordinate and facilitate information exchange between each jurisdiction. Specific duties relating to the underlying information rules are spelled out in the Master Agreement; these include monitoring the implementation of bilateral water management agreements that are to be completed between jurisdictions that share part of the MRB, creating State of the Aquatic Ecosystem reports for the responsible ministers every five years, reviewing the terms of the Master Agreement and making recommendations for revision to the ministers at least every three years, encouraging consistent monitoring programs, and recommending uniform water quality and quantity objectives. The board is also charged with considering the needs of Aboriginal peoples, keeping them informed of the MRB in culturally relevant ways, and incorporating traditional ecological knowledge and values. Payoff rules are clear-cut. The Master Agreement specified that the total annual costs to be shared by the parties shall not exceed $\$ 280,000$ (Part D, Section 3), an amount that has not been increased since 1997.

The MRB Board's mandate is broader than was considered ideal by the officials from Alberta and Saskatchewan who participated in the negotiation of the Master Agreement. These jurisdictions had prior experience with another Canadian internal transboundary agreement, the 1969 Master Agreement on Apportionment among Alberta, Saskatchewan, Manitoba, and Canada, which created the Prairie Provinces Water Board (PWBB). The 1969 agreement apportions the waters of the Saskatchewan River system in southern Canada, which flows through Alberta, Saskatchewan, and Manitoba (Percy 2012). It tasks the PPWB with ensuring that each jurisdiction receives its full allocation, facilitating information exchange, and preventing and resolving disputes (Saunders and Wenig 2006). Board members from Alberta and Saskatchewan preferred the narrower scope of the PPWB (key informant 7). However, with its focus on principles of ecological integrity and sustainable water management, the Master Agreement has a much broader scope than the 1969 Master Agreement on Apportionment for the prairie provinces (Saunders 2012). The Government of the Northwest Territories believes this broader approach is more appropriate because of the more complex situation in the MRB (key informant 2).

In terms of authority rules, the MRB Board is an institution designed to facilitate and coordinate rather than to regulate. It does not have authority independent from the governments that created it. It does not issue licenses or make resource management decisions. It can influence decisions by providing information and acting as a "friend of the tribunal" in provincial, territorial, and federal public hearings (Donihee et al. 2000). However, the MRB Board has no authority to intervene in the parties' jurisdiction; indeed, Part G of the Master Agreement explicitly protects the "proprietary rights or interests of the Parties." This institutional design was purposeful. None of the jurisdictions wanted to cede their autonomy to make resource management decisions or to influence their development trajectory to a multijurisdictional management board (key informant 4).

Despite some disagreement about the board's design and role, there was enough of a consensus that the Master Agreement was signed by the parties. Undoubtedly part of the reason for this agreement was the fact that the Master Agreement is nonbinding, its language is vague, and its principles rely upon the fulfillment of the bilateral water management agreements that were to be negotiated in future. This definitional vagueness and openness can be interpreted as desirable; it reflects principles of adaptive management related to flexibility and leaves options open for future water managers. However, without specific definitions and water quality or quantity targets or recommendations, the agreement's implementation is also vulnerable to fluctuations in the desire of governments to cooperate and adhere to the principles of the agreement. For example, in the years since the agreement was signed, major industrial developments, including the expansion of oil sands extraction and hydroelectric facilities, have raised significant concerns for downstream governments. In recent years, the federal government prioritized increasing 
resource development in Canada; there are strong interests associated with expanding resource development in the MRB (Clancy 2014). Upstream hydroelectric developments and oil sands development in Alberta inspired the creation of the NWT's water strategy (Box 1), the success of which depends strongly on the existence of bilateral agreements that respect the NWT's concerns.

\section{Box 1}

The Northwest Territories Water Strategy

Aboriginal peoples residing in the NWT have a history of partnership with government in making decisions about land and water resources. This is demonstrated in the NWT's recent water strategy, Northern Voices, Northern Waters, which states "today, as in the past, the deeply held values of Aboriginal people have brought water issues to the forefront of the NWT" (GNWT 2010:3). The water strategy, which was developed in partnership between the Government of the Northwest Territories and Aboriginal governments, recognizes the cultural, spiritual, and historical importance of water to Aboriginal people and outlines a commitment to appropriately involve Aboriginals in implementing the water management strategy. In the words of one key informant, "A lot of our perspective is driven by the people who were born and raised and lived in the NWT since time immemorial, which is the Aboriginal population." (key informant 3)

In response to perceptions of deficiencies in the Master Agreement's implementation, the most downstream jurisdiction in the basin, the NWT, has recently been advocating for changes to the MRB Board's membership and funding because it views the board as ineffective, lacking independence from government, and missing needed authority (key informants 2 and 3). The NWT's Minister of Environment and Natural Resources, Michael Miltenberger, made several unsuccessful attempts to meet with the other ministers to discuss reforming the board within the confines of the Master Agreement (key informant 5). However, because water is rarely a key issue for ministers, and when it is, it competes with a host of other issues (Clancy 2014), the interjurisdictional consensus required to modify instructions given to the MRB Board has not been forthcoming. The fact that provinces and territories have different perspectives on what the MRB Board's role should be is also a factor.

As noted above, since the Master Agreement was signed in 1997, three bilateral agreements have been completed. In the case of the 2000 agreement between the Yukon and the NWT, the issues were relatively straightforward and the stakes much lower than is the case between British Columbia and Alberta, or Alberta and the NWT (Saunders 2012). The agreements signed in 2015 were the result of the NWT's strong desire to secure bilateral agreements. In an effort to reinvigorate and align the process of creating bilateral agreements, the Bilateral Water Management Agreements Guidance Document was created (MRBB 2009), largely under the leadership of the NWT (key informant 3). This document (MRBB 2009) provides common guidelines so that each of the bilateral agreements to be negotiated will be complementary; several interviewees reported that it was helpful in the negotiation of the agreements (key informants 9 and 10).
The bilateral agreements completed in 2015 reflect some aspects of Bilateral Water Management Agreements Guidance Document. They include commitments to develop transboundary objectives for surface and ground water quality and quantity and aquatic ecosystem health. Objectives will be developed based on monitoring and learning plans developed by bilateral management committees (BMCs). The agreements also reaffirm the guiding principles of the Master Agreement. However, unlike the Bilateral Water Management Agreements Guidance Document, which outlines a future role the Environment Canada Board may have that is specific to monitoring the implementation of the bilateral agreements (one of its responsibilities under the Master Agreement), the agreements do not assign the MRB Board this responsibility. Rather, the agreements create BMCs, composed of government appointees, and assign them responsibilities associated with implementing the agreement and reporting on the progress of doing so. Perhaps more importantly for the purpose of this paper is the limited role envisioned for the MRB Board, which is mentioned only twice in the agreements: in relation to roles identifying basin-wide research priorities and in the context of helping to resolve disputes that have been referred to the MRB Board (Government of Alberta and Government of the Northwest Territories 2015, Government of British Columbia and Government of the Northwest Territories 2015). The appendices acknowledge that the MRB Board will have an oversight role in implementing the agreement, but are sparse on details regarding what that will entail.

The extent to which the MRB Board will undertake basin-level research, resolve disputes, and provide oversight is uncertain, in part because of the constraints under which it operates. As Donihee et al. (2000) point out, even without the bilateral water management agreements, the MRB Board could play a more active and engaged role in transboundary water governance in the basin. In the next section, we explore why this has not occurred.

\section{PERFORMANCE OF THE MRB BOARD AS A COORDINATING RIVER BASIN ORGANIZATION}

Evaluation of the performance of river basin organizations was a key goal of the papers in this Special Feature. We evaluated the MRB Board relative to four interrelated performance considerations identified by D. Huitema and S. Meijerink (unpublished manuscript), i.e., coordination, accountability, legitimacy, and environmental effectiveness. This facilitated our consideration of the potential for a more adaptive approach to transboundary water governance in the MRB. Except as noted below, we have adopted the definitions of these terms as provided by Huitema and Meijerink (unpublished manuscript).

\section{Coordination}

Coordination is arguably one of the MRB Board's most important functions. However, despite the Master Agreement's promotion of a more holistic approach to management of the waters of the basin, the kind of coordination that the board can undertake is circumscribed by the authority rules contained in the Master Agreement (Table 1). To illustrate, nothing in the wording of the Master Agreement requires or permits the MRB Board to respond proactively to developments in any jurisdiction even if these developments have transboundary implications (Donihee et al. 2000). The board could play a legitimate role as an intervener in provincial planning and regulatory processes to 
provide information or advance general principles. However, advancing specific positions supporting or opposing particular projects would run contrary to the Master Agreement's clauses relating to cooperation and respect for each of the parties' jurisdiction (Donihee et al. 2000).

Concern for jurisdictional interests has meant that at times, the MRB Board struggles to adopt a whole-basin perspective, according to several interviewees (key informants 1, 3, and 7). Although the MRB Board provides a forum to share information, one interviewee commented that there is no mechanism or requirement that other jurisdictions modify internal management procedures in response to concerns raised at meetings (key informant 11). This is reinforced by provisions of the Master Agreement that protect jurisdictional autonomy to make resource management decisions. In fact, coordinating the sometimescompeting interests that exist in the basin regarding industrial development has been a challenge. For example, flow regulation by hydroelectric facilities in British Columbia has been a longstanding concern for downstream jurisdictions Alberta and the NWT (Northern River Basins Study Board 1996). However, when British Columbia approved its third dam on the Peace River, the project's approval conditions did not incorporate the immediate downstream concerns regarding the adequacy of proposed minimum flows from the dam (British Columbia Environmental Assessment Office 2014, Moore 2014).

The Master Agreement does permit jurisdictions to strengthen the coordination function through bilateral agreements. For instance, the bilateral agreements completed in 2015 contain specific requirements and obligations regarding notification and consultation. Significantly, they assign notification and consultation functions to the BMCs. It is possible that the experiences and perspectives from each of the separate BMCs could be brought to the MRB Board. However, the agreement and appendices are silent on whether the BMCs will coordinate with one another or the board. This omission is a concern because coordination and vertical information sharing via nested institutions are key components of adaptive transboundary governance.

Dispute resolution is a common function of river basin organizations in other parts of the world (Huitema and Meijerink 2014). By helping to resolve disputes, river basin organizations can support coordinated approaches to the governance of shared basins. The MRB Board can play a role in resolving disputes when questions or disputes relating to the Master Agreement are brought directly to the board by a member (Donihee et al. 2000) or a BMC (Government of Alberta and Government of the Northwest Territories 2015, Government of British Columbia and Government of the Northwest Territories 2015). However, reflecting the limited and carefully constrained role that the parties to the Master Agreement wanted when it was negotiated, the board can only issue conclusions and recommendations in such cases, and the parties involved need not respond. Furthermore, as Saunders (2012) notes, the Master Agreement does not permit either a judicial role or any form of binding arbitration, meaning that the dispute resolution procedures it contains are weak. The pattern of avoiding binding, judicial dispute resolution was replicated in the recently completed bilateral water management agreements.
The MRB Board has a mandate to recommend objectives for water quality and quantity, which is another avenue for coordination that would support a bioregional perspective. However, it does not have the authority to ensure or require that the basin jurisdictions have common policies (key informant 4). Completed bilateral water management agreements do contain provisions to develop specific surface and ground water quality and quantity objectives, and biological objectives. Objectives have yet to be determined, but will be based on learning plans developed and implemented by BMCs (Government of Alberta and Government of the Northwest Territories 2015, Government of British Columbia and Government of the Northwest Territories 2015). However, the bilateral agreements indicate that monitoring and reporting associated with water quality and quantity objectives will be undertaken by BMCs, not the MRB Board, which may challenge a bioregional approach to governance in the basin.

The MRB Board has a mandate to conduct research and to generate information that contributes to a bioregional perspective on water-related issues. In fact, this is one of the two roles assigned to the MRB Board in the bilateral agreements. In a thorough assessment of the Master Agreement from a legal perspective prepared for the board, Donihee et al. (2000) suggested that bilateral agreements are not necessarily required for the board to address basin-wide issues relating to the sustainable use of water resources or aquatic ecosystems in a more proactive fashion. Despite this opinion, the board has not pursued this opportunity. Instead, it has focused its energy on the production of State of the Environment reports; submissions of these to the Ministers is required every five years under the terms of the Master Agreement. Two such reports have been submitted (MRBB 2003, 2012). The second report was several years overdue; it provided a brief overview and summary of key issues in the basin raised in the first report (MRBB 2012).

The MRB Board has a special mandate to involve Aboriginal peoples in its deliberations and to integrate traditional knowledge, an important feature of the agreement that can contribute to adaptive governance in the basin. Aboriginal board members are explicitly not representatives of the general public. Instead, they are supposed to represent the interests of Aboriginal peoples in the provinces/territories from which they were appointed. This is a complex task because of the diversity of Aboriginal peoples in each jurisdiction; as noted in Section 2 of the Master Agreement, the basin is home to distinct First Nations, Métis, and Inuvialuit peoples. Because of the existence of land claims agreements in the territories that assign specific governance functions to Aboriginal peoples, the legal position of Aboriginal peoples in those jurisdictions differs from the position of Aboriginal peoples in the provincial portions of the basin. Practical challenges also exist relating to the ability of the Aboriginal members of the board to participate in its activities. For instance, resources to support capacity building have been insufficient (key informant 7). Most significantly for the subject of coordination, the role that has been permitted to the Aboriginal board members has been described as "token" by a senior territorial official (key informant 2); this is completely unacceptable from the perspective of the NWT, the interviewee suggested, where Aboriginal governments are viewed as partners with the territorial government (Box 1). 
The MRB Board's performance of its coordination functions should not be surprising in light of the constraints under which it operates. For its day-to-day work, the board has a secretariat with a staff of one person (MRBB 2013). Interviewees emphasized that the budget of the MRB Board, which has not been increased since 1997, is too limited to undertake significant original research. Additionally, as a former executive director noted, the different jurisdictions have struggled to come to agreement on what research initiative should be undertaken with the limited funds that are available (key informant 7). He attributes this in part to the board's composition. Along with several other interviewees, he noted that the board is dominated by bureaucrats, and that this can work against a broader perspective because the government members are focused too strongly on the interests of their own jurisdictions. Funds also have been insufficient to coordinate the various monitoring programs within the basin jurisdictions (key informant 5). The fact that the recent monitoring program instituted in 2012 for the oil sands because of public and scientific concerns is a joint initiative between Canada and Alberta (Government of Canada and Government of Alberta 2012), and does not involve the MRB board, raises questions about the relevance of the board and the strength of the political commitment to shared management of the basin. The Government of the Northwest Territories (GNWT 2012) has requested unsuccessfully that its Aboriginal partners be involved in the implementation of the monitoring program. In 2014, the Auditor General of Canada reviewed the monitoring program's performance and noted that "further efforts are needed to meet commitments to engage stakeholders, including First Nations and Métis, and incorporate TEK [traditional ecological knowledge]" (Auditor General of Canada 2014:17).

\section{Accountability}

How accountability should be evaluated in a case such as the MRB Board is complicated and contested. The MRB Board was created by ministers from the respective jurisdictions. It exists at the pleasure of these ministers and is formally accountable only to them; from this perspective, a former board member suggested, accountability is not a concern (key informant 4). In contrast, other interviewees pointed to larger accountability questions. For example, the respective ministers are under no obligation to present reports from the board to their respective legislatures or to the general public (key informant 3). Hence, the ministers themselves are not regularly accountable for the success or failure of the board to achieve its mandate, or for the extent to which the terms of the Master Agreement are met (key informant 5). The fact that water is rarely a key priority for ministers (Clancy 2014), with perhaps the more recent exception of Minister Miltenberger, has contributed to the low level of political attention the board has received.

The MRB Board's accountability to Aboriginal peoples in the basin also is an important question that deserves consideration (key informant 5). In terms of the legal text of the Master Agreement, the board is not specifically accountable to Aboriginal peoples in the same way it is accountable to the ministers. From the perspective of the NWT, however, the question of accountability to Aboriginal peoples is less clear-cut. As noted previously, Aboriginal governments are viewed as partners by the Government of the Northwest Territories (Box 1). This stands in contrast to the general perspective of the provincial and federal governments in Canada toward Aboriginal peoples (Phare 2009). Gaps in mechanisms to engage the public and uneven approaches to engaging Aboriginal peoples in the basin may challenge adaptive governance.

Key informants reported varying levels of satisfaction regarding the extent to which the MRB Board was filling its mandate. Referring to the kinds of issues discussed above, some interviewees suggested that the board was not particularly effective in fulfilling its mandate under the Master Agreement, and, importantly, was not being held to account. For example, the board is required to submit reports annually. However, it did not publish any annual reports during the years 2007-2011 and fulfilled its overdue reporting requirements with an update in 2013 (MRBB 2013). As noted earlier, the MRB Board was late in delivering its second State of the Aquatic Ecosystem report. The board also has a specific mandate to incorporate traditional ecological knowledge, but has struggled to do so according to interviewees. In a recent report, the board itself acknowledged that "when compared with the availability of western science, Traditional Knowledge is underrepresented in all areas of the Mackenzie River Basin” (MRBB 2012:10).

These kinds of concerns speak to accountability in the sense that historically it does not seem to have mattered to all the signatories to the Master Agreement whether or not the MRB Board fulfills its mandate. In fairness, however, it must be emphasized that it is entirely within the power of the basin jurisdictions (with the consent of all parties) to increase the board's budget, to change the instructions given to government members regarding their role on the board, to encourage the board to expand its activities within its mandate, to provide it with the support it would need to integrate traditional ecological knowledge more effectively, or even to reconstitute the board through a new agreement. Any of these activities would require the consent of all basin jurisdictions. Although most jurisdictions agree that modifying the budget is necessary, agreement on the precise nature of the changes has not been forthcoming (key informant 3; MRBB 2013).

\section{Legitimacy}

As in the case of accountability, multiple perspectives exist regarding the legitimacy of the MRB Board. The concept of legitimacy is conventionally defined as the approval of institutions by those subject to their actions (Suchman 1995, Gearey and Jeffrey 2006). The MRB Board has the legitimacy that flows to bodies constituted under agreements entered into by parties that themselves have legitimacy. It certainly has not exceeded its mandate, or even (arguably) reached the limits of its mandate (Donihee et al. 2000, Saunders 2012).

Legitimacy is often evaluated in terms of inputs and outputs (see Huitema and Meijerink 2014). On the input side, the MRB Board has provided a forum for the parties to share information. Discussions around the board table are private, and minutes of these discussions are not publicly available. Thus, the MRB Board creates a safe environment in which dialogue can occur and contentious issues can be discussed (key informants 3 and 6). The fact that it has a poor track record of engaging the general public within the basin or indeed being known to residents of the basin, a problem identified by several respondents, also does not undermine its legitimacy from this perspective; this kind of engagement was not sought by the signatories to the Master 
Agreement, although strengthening ties to the public may be necessary to establish a more adaptive approach in the basin. Where the MRB Board clearly falls short on the input side is in meeting the requirement to engage Aboriginal peoples and to make effective use of traditional ecological knowledge. The board itself identified this as a deficiency (MRBB 2012). The board's Traditional Knowledge and Strengthening Aboriginal Partners Committee has been working to encourage best practices in gathering and incorporating traditional knowledge in environmental monitoring and assessment to address this deficiency (Stevensen 2012).

On the output side, the MRB Board falls short relative to its specific mandate to provide annual reports and State of the Environment reports every five years. Numerous relevant concerns relating to output legitimacy were identified above. Importantly, some interviewees pointed to the slow pace at which bilateral agreements have been developed as evidence of the board's ineffectiveness. We suggest this criticism is unfair because the Master Agreement assigns the board no role in the negotiation of the bilateral agreements. The rate of progress in negotiating the bilateral agreements has been determined entirely by the signatories to the Master Agreement, rather than by the board.

\section{Environmental effectiveness}

The Master Agreement includes protection of the ecological integrity of the MRB as a guiding principle, but the recently completed bilateral water management agreements assign responsibilities for monitoring and reporting on environmental performance to BMCs, which are separate from the MRB Board. Poor or limited baseline data and inadequate monitoring have made evaluating environmental performance within the basin difficult (MRBB 2012). As a result, assessing the environmental performance of the MRB Board is challenging because of gaps in knowledge regarding pre- and post-MRB Board environmental conditions. Unfortunately, these gaps in knowledge may challenge adaptive governance, which requires ecological baselines that can be used to measure changing ecosystem dynamics. However, it is important to remember that the MRB Board does not have the authority to intervene directly in the environmental decision making of the parties. Any evaluation of the environmental performance of the board must be conducted with reference to the constraints under which it functions. Ultimately, it is the provinces, territories, and federal government that are responsible for environmental outcomes within the basin. Their responsibilities are being pursued through the bilateral agreements and BMCs, within which the MRB Board is not given an ongoing role.

\section{CONCLUSIONS}

A bioregional approach was established in the MRB in 1997 with the signing of the Master Agreement and creation of the MRB Board. However, based on our assessment of the MRB Board's coordination, accountability, legitimacy, and environmental effectiveness, we question whether a bioregional, adaptive approach has been achieved in this basin. Our concerns are based on several pieces of evidence. First, the fairly marginal role the MRB Board has historically played in the basin and the recently completed bilateral agreements, which assign the board very limited roles, suggest that it may not play an engaged and active role in promoting bioregional governance in the basin. Second, challenges associated with including traditional knowledge invite questions regarding the extent to which knowledge from multiple sources will meaningfully inform monitoring and decision making. That the bilateral agreements acknowledge that traditional knowledge, along with scientific and local knowledge, will inform the creation of specific water quality, quantity, and biological objectives is a positive improvement in terms of the inclusion necessary to contribute to adaptive governance. However, the agreements have not yet been implemented. Furthermore, because there is no indication in the agreements that the BMCs will coordinate with one another or with the board, there is considerable uncertainty regarding the extent to which a nested, multilevel approach has been achieved. Finally, although the Master Agreement that created the board can be characterized as flexible, because it avoids precise definitions and leaves details to be specified by bilateral agreements, that openness has also formed the institutional context in which industrial developments with transboundary implications have continued to expand in upstream portions of the MRB. This leads us to our concluding reflections: Although institutional design that facilitates coordination is necessary, it is far from sufficient. Ultimately, institutions work according to the political contexts in which they are embedded.

Consider first the MRB Board, the only institution designed to coordinate at the scale of the bioregion. Its limited financial support and staffing, and the desire of jurisdictions to maintain autonomy to make decisions about resource development without external interference, have resulted in it playing a reactive and limited role in the basin. Jurisdictions have not opted to strongly reinforce a bioregional approach through the bilateral agreements. Instead of reinvigorating the board to play a more proactive role through recently completed bilateral agreements, BMCs are assigned many of the MRB Board's core functions of coordination and monitoring. The bilateral agreements and appendices are silent on whether coordination will occur between and among the BMCs and the MRB Board. Therefore, the extent to which vertical and horizontal information sharing will occur as the agreements are implemented is uncertain. This omission is unfortunate; as one interviewee remarked, sufficiently protecting and, in some cases, restoring the ecosystem integrity require a much more cooperative and inclusive collaborative effort than has been forthcoming (key informant 17). The creation of BMCs alongside the MRB Board does create a multilevel design and, at face value, provides a nested approach to bioregional governance. However, the board's limited mandate and funding mean that it cannot proactively respond to emerging issues in the basin. The interjurisdictional consensus required to alter the MRB Board's instructions and funding arrangements has not been forthcoming. Furthermore, capitalizing on the nested approach will likely require a much more inclusive and coordinated approach than has existed.

As several interviewees pointed out, concerns about respecting jurisdictional autonomy have meant that underlying issues associated with how hydroelectric facilities are operated and the pace and scale of oil sands development are not up for discussion at the interjurisdictional level (key informants 3 and 18). As noted previously, the federal government tends not to intervene in resource matters perceived to be provincial (Saunders 2014) and in recent years has pursued increasing resource development, 
which critics suggest has restricted its agenda for environmental protection (Clancy 2014). The fact that the MRB Board has struggled to meaningfully incorporate traditional knowledge is another deficiency, considering the importance to adaptive governance of including a variety of knowledges in monitoring and decision making. The board's work to address this shortcoming is promising. The fact that traditional knowledge, along with scientific, social scientific, and local knowledge, may be used to develop transboundary water quality and quantity objectives indicates a desire and willingness to incorporate multiple sources of information in the implementation of bilateral management agreements. However, it is important to recognize that the provinces and territories approach consultation with Aboriginal peoples very differently, and these differences may challenge the meaningful inclusion of Aboriginal peoples and traditional knowledge across the entire basin. Historical and current power asymmetries have made including traditional knowledge difficult in the past (Stevenson 2013), and the bilateral agreements do not directly address Canada's colonial legacy, such as the significant disparities in health, education, and income that exists between Aboriginal and non-Aboriginal Canadians (Truth and Reconciliation Commission of Canada 2015).

We close by returning to one of the underlying themes of this Special Feature: the importance and limitations of institutional design. The constraints under which the MRB Board operates exist by design. At the time the Master Agreement was negotiated, the jurisdictions wanted an institution to coordinate information exchange but with no authority to intervene in interjurisdictional matters. The consensus that existed regarding principles of ecosystem integrity and sustainable water management fell apart when momentum and resources were insufficient to fully implement the agreement (key informant 1). The interjurisdictional cooperation and willingness to collaborate that existed in the 1970s and 1980s have greatly diminished today. The federal government has been hesitant to play a leadership role in environmental matters. This hesitance is compounded by recently completed devolution agreements with the territories, through which responsibilities of resource management in the territories were transferred from the federal government to the territorial governments. Furthermore, in recent years, the federal government has pursued a policy of reducing regulatory burdens for industry, including restricting the scope and application of federal environmental protections for water (Clancy 2014).

Paradoxically, this case study illustrates that although institutional design that facilitates coordination is necessary, it is far from sufficient. The presence of a river basin organization does not necessarily result in adaptive governance. The willingness to effectively coordinate and to manage the MRB according to principles of ecosystem integrity and sustainability depends strongly on the desire of the jurisdictions to do so. As we have demonstrated, that desire has not always been consistent in the MRB. The bilateral agreements represent a renewed commitment to the principles of the agreement and perhaps a new beginning for cooperative and adaptive governance in the basin. The extent to which they can contribute to a bioregional, adaptive approach to governance in the basin will require addressing deficiencies associated with including traditional knowledge and coordinating the various interests at stake in resource development in the basin. It will certainly require coordination between separate BMCs, either organically or through the MRB Board. Achieving this level of coordination could make governance in the MRB a positive example of an adaptive governance regime that proactively responds to emerging threats in the basin.

Responses to this article can be read online at: http://www.ecologyandsociety.org/issues/responses. $\mathrm{php} / 8301$

\begin{abstract}
Acknowledgments:
An earlier version of this article was published: de Loë, R., and M. Morris. 2014 Cooperative transboundary water governance in Canada's Mackenzie River Basin: status and prospects. Pages 67-95 in D. Huitema, and S. Meijerink, editors. The politics of river basin organizations, coalitions, institutional design choices and consequences. Edward Elgar Publishing, Cheltenham, UK. The authors wish to thank Edward Elgar Publishing who have kindly given permission for the use of this material. This article has been substantially updated to reflect the focus of this special issue on bioregionalism, the addition of considerable new data collected by the first author, and new developments in the negotiations of the transboundary agreements. We are grateful to the 19 people who shared their insights during interviews. Many of the people to whom we spoke were playing roles, either direct or indirect, in ongoing negotiations for bilateral water management agreements. We are thankful they were willing to share their views during this busy time. Thank you to Rob Wunderink for preparing the map. We would also like to thank the two anonymous reviewers for their constructive feedback. As the authors of this chapter, we are responsible for the ways in which the interviews were used and interpreted in this article.
\end{abstract}

\section{LITERATURE CITED}

Aboriginal Affairs and Northern Development Canada and Government of the Northwest Territories. 2011. Our water, our life: building partnerships to assess the health of the Slave River and Slave River Delta. Government of the Northwest Territories, Yellowknife, Northwest Territories, Canada.

Akamani, K., and P. I. Wilson. 2011. Toward the adaptive governance of transboundary water resources. Conservation Letters 4(6):409-416. http://dx.doi.org/10.1111/j.1755-263x.2011.00188. $\underline{x}$

Alberta Energy Regulator. 2015. Alberta's energy reserves 2014 and supply/demand outlook 2015-2024. Alberta Energy Regulator, Calgary, Alberta, Canada.

Alberta Energy and Utilities Board. 2001. Alberta's reserves 2000 and supply/demand outlook 2001-2010. Alberta Energy and Utilities Board, Calgary, Alberta, Canada.

Auditor General of Canada. 2011. Assessing cumulative effects of oil sands projects. Pages 1-20 in Report of the Commissioner of the Environment and Sustainable Development. Office of the Auditor General of Canada, Ottawa, Ontario, Canada.

Auditor General of Canada. 2014. Environmental monitoring of oil sands. Pages 61-82 in Report of the Commissioner of the Environment and Sustainable Development. Office of the Auditor General of Canada, Ottawa, Ontario, Canada. 
Beltaos, S. 2014. Comparing the impacts of regulation and climate on ice-jam flooding of the Peace-Athabasca Delta. Cold Regions Science and Technology 108:49-58. http://dx.doi.org/10.1016/j. coldregions.2014.08.006

Bhat, A. 2009. The politics of model maintenance: the Murray Darling and Brantas River Basins compared. Water Alternatives 1(2):201-218.

Booth, L. and F. Quinn. 1995. Twenty-five years of the Canada Water Act. Canadian Water Resources Journal 20(2):65-90. http:// dx.doi.org/10.4296/cwrj2002065

British Columbia Environmental Assessment Office. 2014. Environmental assessment certificate \#E14-02. Environmental Assessment Office, Victoria, British Columbia, Canada.

Canadian Association of Petroluem Producers. 2015. Water use. Canadian Association of Petroluem Producers, Calgary, Alberta, Canada. [online] URL: http://www.canadasoilsands.ca/en/ explore-topics/water-use

Chaffin, B. C., H. Gosnell, and B. A. Cosens. 2014. A decade of adaptive governance scholarship: synthesis and future directions. Ecology and Society 19(3):56. http://dx.doi.org/10.5751/ ES-06824-190356

Clancy, P. 2014. Freshwater politics in Canada. University of Toronto Press, Toronto, Ontario, Canada.

Cosens, B. A., and M. K. Williams. 2012. Resilience and water governance: adaptive governance in the Columbia River basin. Ecology and Society 17(4):3. http://dx.doi.org/10.5751/ES-04986-170403

Creery, R. A. 1979. Avoiding further downstream crises: the Mackenzie River Basin Committee. Canadian Water Resources Journal 4(3):60-66. http://dx.doi.org/10.4296/cwrj0403060

De Stefano, L., J. Duncan, S. Dinar, K. Stahl, K. M. Strzepek, and A. T. Wolf. 2012. Climate change and the institutional resilience of international river basins. Journal of Peace Research 49(1): 193-209. http://dx.doi.org/10.1177/0022343311427416

Delli Priscoli, J., and A. T. Wolf. 2009. Managing and transforming water conflicts. Cambrige University Press, Cambridge, UK. http://dx.doi.org/10.1017/cbo9780511551536

Donihee, J., S. A. Kennett, and J. O. Saunders. 2000. Defining a role for the Mackenzie River Basin Board: a review of key considerations and options. Canadian Institute of Resources Law, Calgary, Alberta, Canada.

Folke, C., T. Hahn, P. Ohlsson, and J. Norberg. 2005. Adaptive governance of social-ecological systems. Annual Review of Environment and Resources 30:441-473. http://dx.doi.org/10.1146/ annurev.energy.30.050504.144511

Garrick, D., G. Anderson, D. Connell, and J. Pittock. 2014. Federal rivers: a critical review of water governance challenges in federal systems. Pages 3-18 in D. Garrick, G. R. M. Anderson, D. Connell, and J. Pittock, editors. Federal rivers: managing water in multi-layered political systems. Edward Elgar, Cheltenham, UK. http://dx.doi.org/10.4337/9781781955055.00010

Gearey, M., and P. Jeffrey. 2006. Concepts of legitimacy within the context of adaptive water management strategies. Ecological Economics 60(1):129-137. http://dx.doi.org/10.1016/j.

ecolecon.2006.02.014
Government of Alberta. 2015. Budget 2015: revenue. Government of Alberta, Edmonton, Alberta, Canada.

Government of Alberta and Government of the Northwest Territories. 2015. Mackenzie River Basin Bilateral Water Management Agreement between the Government of Alberta and the Government of the Northwest Territories. Government of Alberta and Government of the Northwest Territories, Edmonton, Alberta, and Yellowknife, Northwest Territories, Canada.

Government of British Columbia and Government of the Northwest Territories. 2015. Mackenzie River Basin Bilateral Agreement Between the Government of British Columbia and the Government of the Northwest Territories. Government of British Columbia and Government of the Northwest Territories, Victoria, British Columbia, and Yellowknife, Northwest Territories, Canada.

Government of Canada and Government of Alberta. 2012. Joint Canada-Alberta Implementation Plan for Oil Sands Monitoring. Government of Canada, Ottawa, Ontario, Canada.

Government of Canada, Government of British Columbia, Government of Alberta, Government of Saskatchewan, Government of the Yukon, and Government of the Northwest Territories. 1997. Mackenzie River Basin Transboundary Waters Master Agreement. Mackenzie River Basin Board, Yellowknife, Northwest Territories, Canada. [online] URL: http://www.mrbb. ca/uploads/files/genera1/19//mackenzie-river-basin-transboundarywaters-master-agreement.pdf

Government of the Northwest Territories (GNWT). 2010. Northern voices, northern waters: NWT water stewardship strategy. Environment and Natural Resources, Yellowknife, Northwest Territories, Canada.

Government of the Northwest Territories (GNWT). 2012. Joint Canada-Alberta Implementation Plan for Oil Sands Monitoring [statement]. Government of the Northwest Territories, Yellowknife, Northwest Territories, Canada. http://news.exec. gov.nt.ca/joint-canada-alberta-implementation-plan-for-oils-sandsmonitoring

Government of the Northwest Territories (GNWT). 2013. GNWT comments on Site C Clean Energy Project. Canadian Environmental Assessment Registry, Yellowknife, Northwest Territories, Canada.

Green, O. O., B. A. Cosens, and A. S. Garmestani. 2013. Resilience in transboundary water governance: the Okavango River Basin. Ecology and Society 18(2):23. http://dx.doi.org/10.5751/ ES-05453-180223

Hodson, P. V. 2013. History of environmental contamination by oil sands extraction. Proceedings of the National Academy of the Sciences of the United States of America 110(5):1569-1570. http:// dx.doi.org/10.1073/pnas. 1221660110

Huitema, D., and S. Meijerink. 2014. The politics of river basin organizations: institutional design choices, coalitions and consequences. Pages 1-37 in D. Huitema and S. Meijerink, editors. The politics of river basin organizations coalitions, institutional design choices and consequences. Edward Elgar, Cheltenham, UK. 
Kelly, E. N., D. W. Schindler, P. V. Hodson, J. W. Short, R. Radmanovich, and C. C. Nielsen. 2010. Oil sands development contributes elements toxic at low concentrations to the Athabasca River and its tributaries. Proceedings of the National Academy of Science of the United States of America 107(37):16178-16183. http://dx.doi.org/10.1073/pnas.1008754107

Kumar, M. D. 2014. The hydro-institutional challenge of managing water economies of federal rivers: a case study of Narmada River Basin, India. Pages 229-242 in D. Garrick, G. R. M. Anderson, D. Connell, and J. Pittock, editors. Federal rivers: managing water in multi-layered political systems. Edward Elgar, Cheltenham, UK. http://dx.doi.org/10.4337/9781781955055.00027

Loures, F., A. Rieu-Clarke, and M. Vercambre. 2008. Everything you need to know about the UN Watercourses Convention. World Wildlife Fund, Gland, Switzerland.

Mackenzie River Basin Board (MRBB). 2003. Highlights of the Mackenzie River Basin Board's State of the Aquatic Ecosystem Report. Mackenzie River Basin Board, Fort Smith, Northwest Territories, Canada.

Mackenzie River Basin Board (MRBB). 2009. Bilateral water management agreements guidance document. Mackenzie River Basin Board, Fort Smith, Northwest Territories, Canada.

Mackenzie River Basin Board (MRBB). 2012. The Mackenzie River Basin Board's 2012 issues report: oil sands development, hydroelectric development, and climate change in the Mackenzie RIver Basin. Mackenzie River Basin Board, Fort Smith, Northwest Territories, Canada.

Mackenzie River Basin Board (MRBB). 2013. Report to the Ministers April 1, 2007-March 31 2012. Mackenzie River Basin Board, Yellowknife, Northwest Territories, Canada..

Mantyka-Pringle, C., C. Westman, A. P. Kythreotis, and D. W. Schindler. 2015. Honouring indigenous treaty rights for climate justice. Nature Climate Change 5:798-801. http://dx.doi. org/10.1038/nclimate2714

McCaffrey, S. C. 2007. The law of international water courses. Second edition. Oxford University Press, New York, New York, USA.

Meruelo, N. 2007. Considering a cooperative management approach in resolving the Apalachicola-Chattahoochee-Flint river basin water war. Fordam Environmental Law Review 18:335-368.

Moore, J. 2014. Closing remarks of Her Majesty the Queen in right of Alberta in relation to B. C. Hydro and Power Authority's proposed Site C Clean Energy Project. Alberta Justice, Edmonton, Alberta, Canada.

Northern River Basins Study Board. 1996. Northern River Basins Study: report to the ministers 1996. Alberta Environmental Protection, Edmonton, Alberta, Canada.

Oil Sands Advisory Panel. 2010. A foundation for the future: building an environmental monitoring system for the oil sands. Environment Canada, Ottawa, Ontario, Canada.

Parks Canada. 2013. Parks Canada's submission to the Joint Review Panel for BC Hydro's Site C Clean Energy Project.
Canadian Environmental Assessment Registry, Ottawa, Ontario, Canada.

Percy, D. R. 2012. Resolving water-use conflicts: insights from the prairie experience for the Mackenzie River Basin. C.D. Howe Institute, Toronto, Ontario, Canada. http://dx.doi.org/10.2139/ $\underline{\text { Ssrn. } 2027634}$

Phare, M. A. 2009. Denying the source: the crisis of First Nations water rights. Rocky Mountain Books, Surrey, British Columbia, Canada.

Prowse, T. D., and F. M. Conly. 2000. Multiple-hydrologic stressors of a northern delta ecosystem. Journal of Aquatic Ecosystem Stress and Recovery 8:17-26. http://dx.doi. org/10.1023/A:1011483504849

Prowse, T. D., C. Furgal, B. R. Bonsai, and D. L. Peters. 2009. Climate impacts on northern Canada: regional background. Ambio 38(5):248-256. http://dx.doi.org/10.1579/0044-7447-38.5.248

Raadgever, G. T., E. Mostert, N. Kranz, E. Interwies, and J. G. Timmerman. 2008. Assessing management regimes in transboundary river basins: do they support adaptive management? Ecology and Society 13(1):14. [online] URL: http:// www.ecologyandsociety.org/vol13/iss1/art14/

Regional Municipality of Wood Buffalo. 2012. Municipal census 2012. Regional Municipality of Wood Buffalo, Fort McMurray, Alberta, Canada.

Rosenberg International Forum on Water Policy. 2013. Rosenberg International Forum: the Mackenzie River Basin. Rosenberg International Forum on Water Policy, Berkeley, California, USA.

Saunders, J. O. 2012. Managing the Mackenzie: negotiating a future with the basin in mind. Resources 114:1-10.

Saunders, J. O. 2014. Managing water in a federal state: the Canadian experience. Pages 76-89 in D. Garrick, G. R. M. Anderson, D. Connell, and J. Pittock, editors. Federal rivers: managing water in multi-layered political systems. Edward Elgar, Northampton, UK. http://dx.doi.org/10.4337/9781781955055.00015

Saunders, J. O., and M. Wenig. 2006. Whose water? Canadian water management and the challenges of jurisdictional fragmentation. Pages 119-141 in K. Bakker, editor. Eau Canada: the future of Canada's water. University of British Columbia Press, Vancouver, British Columbia, Canada.

Sauchyn, D. J., J.-M. St-Jacques, and B. H. Luckman. 2015. Longterm reliability of the Athabasca River (Alberta, Canada) as the water source for oil sands mining. Proceedings of the National Academy of the Sciences of the United States of America 112 (41):12621-12626. http://dx.doi.org/10.1073/pnas.1509726112

Schnorbus, M., K. Bennett, A. Werner, and A. Berland. 2011. Hydrologic impacts of climate change in the Peace, Campbell and Columbia Watersheds, British Columbia, Canada. Pacific Climate Impacts Consortium, University of Victoria, Victoria, British Columbia, Canada.

Schindler, D. W., and W. F. Donahue. 2006. An impending water crisis in Canada's western prairie provinces. Proceedings of the National Academy of Science of the United States of America 103 (19):7210-7216. http://dx.doi.org/10.1073/pnas.0601568103 
Slocombe, D. S. 1998. Lessons from experience with ecosystembased management. Landscape and Urban Planning 40:31-39. http://dx.doi.org/10.1016/S0169-2046(97)00096-0

Statistics Canada. 2012. Population and dwelling counts, for Canada, provinces and territories, and census subdivisions (municipalities), 2011 and 2006 censuses. Statistics Canada, Ottawa, Ontario, Canada. [online] URL: http://www12.statcan. gc.ca/census-recensement/2011/dp-pd/hlt-fst/pd-pl/Table-Tableau. $\underline{\mathrm{cfm}}$ ?LANG $=$ Eng $\& \mathrm{~T}=302 \& \mathrm{SR}=426 \& \mathrm{~S}=51 \& \mathrm{O}=$

$\underline{\mathrm{A} \& \mathrm{RPP}}=25 \& \mathrm{PR}=48 \& \mathrm{CMA}=0$

Stevenson, M. G. 2012. Towards a new current of thought: best practices in gathering and incorporating traditional ecological knowledge into environmental monitoring and assessment. Mackenzie River Basin Board, Yellowknife, Northwest Territories, Canada.

Suchman, M. 1995. Managing legitimacy: strategic and institutional approaches. Academy of Management Review 20 (3):571-610.

Timoney, K. P., and P. Lee. 2009. Does the Alberta tar sands industry pollute? The scientific evidence. Open Conservation Biology Journal 3:65-81. http://dx.doi.org/10.2174/1874839200903010065

Truth and Reconciliation Commission of Canada. 2015. Honouring the truth, reconciling for the future: summary of the final report of the Truth and Reconciliation Commission of Canada. Truth and Reconciliation Commission of Canada, Winnipeg, Manitoba, Canada.

Wolfe, B. B., R. I. Hall, T. W. D. Edwards, and J. W. Johnston. 2012. Developing temporal hydroecological perspectives to inform stewardship of a northern floodplain landscape subject to multiple stressors: paleolimnological investigations of the Peace-Athabasca Delta. Environmental Reviews 20:191-210. http://dx.doi.org/10.1139/a2012-008 